UDC $1 / 14$

Evangelos MOUTSOPOULOS

\title{
PHILOSOPHY EMBRACING HUMANITIES
}

\begin{abstract}
This paper discusses the following points of the history of philosophy and modern life. The emergence of philosophy - the longing for wisdom - in Ancient Greece as the historical point of formation of human rational reasoning. The formation of the ideal of kalokagathia - the art of fine speeches - as the main factor that initiated studia humaniora in Roman culture and the tradition of humanities in present days. The Greek language and literature as carriers of wisdom of Antic world that gave birth to Neoplatonism and Christian philosophy and mysticism. The rehabilitation of Aristotle's Organon as the way to Neohellenic philosophy and the advent of the European Renaissance. Greek philosophy becoming an inseparable part of humanities in modern times. The unprecedented growth of technologies and globalization pushing aside philosophy and humanities in the interest of profit and immense wealth. The paradigm of corruption as the cause of worldwide detriment of individuals. Humanities and philosophy as the only warrants of an effective transition towards sane societies.
\end{abstract}

Keywords: Greek philosophy, the rise and decline of humanities, the unity of philosophy and humanities, globalization and profits, returning to sane society.

It seems to be an undoubted fact, that the birth of philosophy that took place around the middle of the VI century B.C. in the rich cities of Ionia, marked the exit of human thought from the era of mythical cognition, thus freeing reason from the bonds of archaic mentality which is similar to the infantile one and becomes similar to immature societies. This was the starting point of a new era, that of scientific inquiry. Before it, wise men had emerged in several cultures of the world. Even in different Greek provinces, or islands wise men arose as celebrities of their time. Pythagoras was the first to decline the title of wise man, stating that he was but longing for wisdom. The term of philosophy had just been coined. Philosophy spread out towards every direction within the Greek world: from Ionia to Thrace and up to Southern Italy and Sicily.

After the Medic wars, thanks to their democratic governance numerous Greek cities, above all Athens, became prominent cultural centers attracting thinkers from everywhere. Particularly in Athens grew the ideal of kalokagathia, the wish to show beautiful and behave virtuously in society while delivering brilliant speeches. This attitude entailed the need of a deep and wide education ensured through studying literary works which provided models of virtue. From such a practice combined to the initiation into rational philosophical thought supposed to lead to happiness 
through the acquisition of virtue, sprang the mentality of favoring the anthropocentric studies and promoting the corresponding values, both of which, some centuries later, fascinated by the Greek culture and having largely adopted it, the Romans would call studia humanio$r a$, a term which evolved through the ages to become in our present days the humanities.

Philosophy has always embraced literary studies. The Platonic Academy and the Aristotelian Lyceum in Athens, after the various Pythagorean schools, namely that of Croton, served as paradigms to the founding of the Bibliotheca Alexandrina established by Ptolemy II Soter, the Greek king of Egypt, parallelly to the Museum, both devoted to the arts and sciences, where famous philologists, philosophers mathematicians and astronomers emerged from. Cultivating both literature and philosophy resulted in the renovation of Neoplatonism by Plotinus who thereafter taught the Roman aristocracy in Greek, the language of the elite within the empire. Proclus, one of the latest successors of Plato at the Academy in Athens, had studied mathematics in Alexandria, but was converted into philosophy and formulated a complete Neoplatonic philosophical system that pertained through the centuries, by giving birth to the Jewish and Islamic mysticisms. A Christian follower of Proclus, probably a certain Peter of Gaza, adapted his master's system to the Christian dogmas, under the pseudonym of Dionysius Areopagita. His main works entitled $\mathrm{On} \mathrm{Di}$ vine Names and Celestial Hierarchy, on their side, after having been translated into Latin, gave birth to the various medieval Christian mysticisms.

In 529 A.D., emperor Justinian edicted the closure of the Academy and fired its professors who were thus obliged to emigrate to Persia. Instead, a university, under control of both the Church and the State, was established in Constantinople, where humanities were cultivated under the supervision of the Church. Meanwhile, a ferocious struggle was taking place in the West, between Realists, of Platonic obedience, and Nominalists, due to the contest about the meaning of a passage from Porphyry's commentary on Aristotle's Organon. The socalled controversy on the genera lasted during some ten centuries. Aristotle's Organon was the only accepted and usefully studied work of the Stagirite who, in contrast to Plato, did not accept that the universe had been created; a thesis contrary to the Judeo-Christian tradition. It was not before the second half of the XIII century that Aristotle's realism was rehabilitated by Thomas Aquinas, i.e. after the Islamic Aristotelian philosophical tradition had transited to Spain along the Southern coasts of the Mediterranean sea. Until that period, the role of philosophy was officially considered as being that of an ancilla, i.e. of a servant of theology, the main discipline. Thomas Aquina's references to Aristotle contained numerous misunderstandings due to erroneous translations from the Greek text into Latin. About the middle of the XIV century, Cydoneus undertook the laborious and tremendous work of translating Thomas' Summa theologica into classical Greek being faithful both to Aquinas, and to the Stagirite's text, thus inaugurating the contacts between the Western and the Neohellenic philosophy, which were to become intensified ever since. The massive exodus of Greek scholars and thinkers to Italy after the fall of Constantinople to the Turks hastened the advent of the Renaissance in every field, but mostly in the field of the humanities. 
In the numerous universities already established or newly created, humanities were cultivated together with philosophy, in order to better understand the message of Antiquity and its meaning, and to take advantage out of it as well. From Italy too, due to the Renaissance, emerged the modern experimental science whose exploits were accounted by Francis Bacon in his Novum Organum which, by its title, referred to Aristotle's six logical treatises. Humanities were thereafter enriched by the contribution of archaeology, both Greek and Roman, which were supposed to complete the knowledge of the ancient world. After Descartes, a philosopher and mathematician who, through fighting the medieval scholasticism with its own weapons, inaugurated a new era in the history of philosophy, the bond between humanities and philosophy was strengthened. In between, the scientific vocabulary was enriched by a Greek terminology, thanks to the wealth of the Greek language and to the study of humanities by the European scientists. With Hegel and his followers, Greek philosophy became an inseparable part of humanities considered as the way towards the completion of man's personality.

The rapid accrescence of sciences and the impressive growing of technology in our days attract the majority of our contemporary consciences in an admirative attitude, exerting upon them a drastic fascination which results in a passive acceptance of their effects. After the industrial revolution, we are experiencing the effects of the technological revolution, together with the specific assistance informatics has imposed, the ideology of globalization, which, alike every ideology, looks as a velvet glove hiding a hideous hand. It merely aims at transforming human personalities into masses, to the interest and profit of particular groups which act worldwide to the detriment of individuals. Even philosophy has become «analytical», reflecting a respective mentality. Humanities are no more taught in most countries, since students are growingly interested in business administration, expecting aleatory lucrative bonuses. Corruption has grown omnipresent, since it is scandalously tolerated, for, everyone has been infected by it. Is it, then, possible, under such conditions, to look after an antidote to administer to humankind in order not even to cure it, but, at least, to stop its further contamination coming from above? Is there any salutary reaction to this degrading and dishonoring situation?

It seems that the answer has to do with the Delphic and Socratic «know thyself», and that it could affect every human consciousness, provided the study of humanities be encouraged among the young generation. These young persons would then understand their rights in connection with those of other people and learn how to moderate their pulsions and their avidity. Humanities together with philosophy, side by side, embracing and completing each other as they did in Antiquity, may become the warrants of an effective transition towards sane societies and virtuous citizens having recovered their dignity. 